\title{
Family Counseling Program for Parents Who Have Autistic Children
}

\author{
Nurhastuti, Fatmawati \\ Universitas Negeri Padang, Indonesia \\ Email: tutibakar@gmail.com
}

\begin{abstract}
The Unpreparedness of parents in taking care of the interests of children with autism will make children continue backward and not ready for the future. In such conditions, it is necessary to support for parents in caring for children with autism. This study was conducted aiming to provide support to parents of children with autism so that the problems arising from the existence of an autistic child can be minimized or even eliminated together. In addition, this research can also be used as a reference for parents who have children with autism in an effort to maintenance and cure children with autism. This research is a qualitative descriptive study. Qualitative research is considered more appropriate to determine the family counseling program for parents who have children with autism in the Autism Institute YPPA Padang. The approach used in this study is deemed appropriate for understanding and motivating parents of children with autism with all complexity as subjective beings.
\end{abstract}

Keywords: autism, parents, family counseling.

\section{INTRODUCTION}

All parents expect to have healthy, boast and perfect children, but sometimes the reality is not in accordance with the wishes. Some parents get what they want, but some others do not. Some of them have children with special needs, such as autism. Autism is one of the extensive neurobiological development disorders in children. Autism is not the mental disorder, but autism occurs because of developmental disorders in the brain that is not able to function properly. Autism is grouped into pervasive developmental disorders located in someone's nervous system (Pratiwi, 2013).

The term autism is used to denote a psychotic phenomenon in unique and prominent children who are often called Kanner syndrome characterized by empty facial expressions as if they were daydreaming, lose their mind and it's hard for others to attract their attention or invite them to communicate (Budiman, 2011). Autism is a complex developmental disorder involving communication, social interaction and imagination activity. The Symptoms begin to appear before the child is 3 years old (Suryana, 2004).

The parent's first reaction when their child is said to be troubled is disbelief, shock, sadness, disappointment, guilt, anger, and refusal (Danuatmaja, 2008), (Suteja, 2014). Not easy for parents whose children have autism to experience this phase, before finally reaching the stage of acceptance There is a time for parents to think and do not know what action to take (Delhpie, 2009).
Acceptance of parents greatly affects the development of autistic children later on (Wijayakusuma, 2011). The attitude of parents who can't accept the fact that their child has an autism disorder will be very bad impact, because it will only make the autistic children feeling not understood and not accepted as they are, a child with autism disorder is still a child who needs attention and love from parents, relatives, and family. (Huzaemah, 2010).

The emergence of wrong parents' behavior towards autistic children is caused by the perception, understanding, and lack of knowledge of parents about children with autism and how to handle it (Danuatmaja, 2008). The first stage of the process of handling autistic children is empowering, that is the process of counseling for parents who aim to elicit acceptance response and also the positive behavior of children with autism (Yuwono, 2010).

Family counseling can provide the mental strength of parents with autistic children who grow differently than children in general (Latipun, 2008). Counselors are expected to provide empowering and useful solutions for parents, families, and children with autism itself. Through this family counseling, it is expected that parents can overcome the problems that may arise because of autistic children so that parents can overcome the problems around them and solve the problem by themselves. 


\section{METHOD}

This research was a descriptive qualitative research that was a method in researching the status of a group of people or an object with the aim to describe systematically, factually and accurately about the facts or phenomena that were investigated (Cevilla, 2014).

This study was conducted at the Institute of Autism YPPA Padang with the number of parents who have children with autism were 13 parents. The subjects of the study were determined by using consecutive sampling which was by recording the parents who had autistic children according to the inclusion and exclusion criteria to fulfill the eligible amount of analysis. This research has been conducted for 2 months, it was between July 2014 until September 2014 at the Institute of Autism YPPA Kota Padang.

Determination of the location of this study was based on the consideration that the selected location can reduce the time constraints and funds owned by the researcher because the location is easy to reach. In addition, the researcher easily gets access to the location to facilitate the search for necessary data.

Data collection techniques used in this study was interviews, observation and literature study. In this research, the technique of analyzing data and data analysis were done in several stages: organizing data; categories, themes, and patterns of answers; seeking alternative explanations for data; as well as writing the research results.

\section{FINDINGS AND DISCUSSION}

\section{Findings}

Parental acceptance of the presence of children with autism disorders, various things can happen to the parents. Parents were usually stressed, disappointed, discouraged, search for treatment everywhere, all worried about the future of their children and others. This is confirmed by Williams \& Wright (2007) who said that the family will go through a series of emotions when their children are said as autism. It varies in every family, and each family has its own emotional journey (Nainggolan, 2016).

Some families have gone through a long diagnostic process and some have to wait a long time for consultation. Some find the process so fast that they have little time to think about the consequences of managing their emotions (Mulana, 2013). In some children, diagnosis is easier to make when the child is younger and in some, the diagnosis is difficult because the problem is easy. All of this can affect how parents will think about what they should do (Safaria, 2010). (Susanto, 2014)
According to Williams \& Wright (2007), all parents have different responses and feelings when their child is diagnosed with autism. Some of the reactions are as follows: (1) Relief, if parents understand about autism and know how to seek expert help; (2) Guilt, is the feeling of parents who worry if they do the wrong thing during pregnancy or nurturing; (3) Losing, if dreams of their children before birth and when they were young can't be fulfilled; (4) Fear of the future, because the family is very afraid of the future of their children and must change their children's future; (5) Looking for information, the family wants to gather as much information as possible and find other families to share experiences. Even if there are some families who may avoid information and try to ignore it.

Problems with parents, shock, and stress will lead to new diseases, disharmony in the family will be fatal, such as the occurrence of divorce. Work productivity decreases and can impact on lay-offs. Eventually, this family will withdraw from the community. Here the presence of a counselor is needed before causing a more bad impact.

Based on the research results towards the informants, the result was obtained as follows: (1) Children with autism are more often with their mothers than their fathers. Besides because the father is the head of the family who responsible for providing a living to the family, it is also a mother has a psychological closeness to their children; (2) Most of the parents who have children with autism in the Institute of Autism YPPA Padang City have undergraduate education background; (3) The majority of informants are Muslims; (4) The most parents' job is entrepreneurship.

Counseling is a process that occurs in a person's relationship with an individual, that is individual who has problems that can't be overcome by themselves, with a professional who has obtained training and experiences to help the client solve their problem.

While the meaning of the family is a bond of living fellowship on the basis of marriage between adults of different kinds who live together or a man or a woman who is alone with or without children, either her own child or adoption and resides in a household (Pujosuwarno, 2007). Thus, family counseling is essentially an application of counseling to a particular situation. This family counseling focuses on issues relating to the family situation and the organization involves family members.

The process of implementing family counseling for parents who have children with autism is done with three stages, namely.

\section{The first interview}

At this stage, the counselor initiates to communicate with a parent who has an autistic child. 
Communication is done by telephone to convey the problems that they experienced in the form of complaints related to the handling of children with autism.

\section{Intermediate interview}

At this stage, the counselor acts as a guide but always tries to avoid taking over the role of parent. The counselor should be neutral and refrain from interfering in a family member's personal affairs, facilitating free and pleasant communication, and also encouraging each family member to participate in the counseling process.

\section{The Last Interview}

Family counseling takes several weekly or monthly sessions. Family counseling can be stopped if family members involved in the family counseling process can work well together as a group to solve problems related to the treatment of autistic children in the family.

After several family counseling activities also indepth interviews and observations, it can be concluded that several family counseling roles for parents with autistic children are as follows:

Develop a Good Relationship, Implementation of family counseling is able to develop good relationships between family members who have children with autism.

A harmonic relationship between family members, In the family counseling that researchers have done, it is emphasized the concept that the family is the primary learning environment for every individual. Therefore, families should be able to provide the best example of education for children, especially for families who have children with autism

Acceptance of family members towards autistic children in the family, After family counseling, it appears that the acceptance of parents and all family members to autistic children is characterized by the presence of attention and affection, giving time to participate in the activities of children and not expecting too much in children.

Develop an Emotional Appreciation, Implementation of family counseling that researchers do is the providing the knowledge about the way parents in giving treatment to children with autism so that emotional appreciation grows in children with autism.

Feelings of wanting to help from family members to autistic children, Family counseling conducted by the researchers turned out to affect all family members. All family members are aware that an autistic child living in the family needs support and assistance so that his or her insight does not have a negative effect on the child or the family.
A sense of love for children with autism, It influences to grow affection from all family members to family members who suffer from autism.

Developing Problem Solving Alternatives, Implementation of family counseling is able to develop problem-solving alternative related to the handling of autistic children in the family.

Identifying the cause of the problem, Family counseling is a place to identify the source of problems surrounding the presence of autistic children in the family. Family counseling can find the problems that exist because through this counseling every member of the family dares to open in revealing all the problems.

Solving problems ideas, If this family counseling can be done, it means that autistic children will get two help as well as internal therapy to solve problems that come from themselves and external therapy to solve problems with the environment.

Applying One of the Alternatives in Problem Solving, After all family members are able to identify the cause of the problem, family members are trained to apply one alternative problem-solving.

Therapy, All family members are able to do therapy for children with autism. Therapy here is meant to provide special training in children with autism by providing positive reinforcement (reward/praise).

Development of knowledge and skills of children with autism, Family members can do developmental therapy in children with autism. In developmental therapy, the child will be studied his interests, strengths and developmental levels, then enhanced his social, emotional and intellectual abilities until the child is really progressing up to his symbolic interactions.

The benefits of family counseling in helping parents who have children with autism can be seen in the development of children with autism in some ways as follows: (1) The development of the physical state and skills of an autistic child, such as: self-help (such as dressing, eating, bathing), helping others (such as helping to clean beds and floors, helping fallen friends), basic skills (such as reading, writing, drawing, counting), play skills (such as biking, skating, swimming); (2) The development of language skills, such as: codes, cues and the use of fingers to communicate words; (3) The development of emotional states, such as emotional calm, form of emotional distribution, and skills to complete various tasks; (4) The development of attitudes and behavior.

Laying the foundation of love and affection in children with autism can be done by the family to grow self-confidence so that autistic children are able to answer the challenges of life and get the achievement. Through family counseling, there will be instilled a sense of responsibility to each family member to solve problems together in dealing with children with autism (Howard, 2012). 


\section{CONCLUSION}

Some conclusions to be found from this research are 1) the role of family counseling for parents who have children with autism includes developing good relationships, developing emotional rewards, developing problem-solving alternatives and implementing one alternative problem-solving; 2) the benefits of family counseling in assisting the therapy process conducted by parents who have children with autism can be seen in the development of children with autism in some ways as follows: (a) physical development; (b) the development of language skills; (c) the development of emotional state; (d) the development of attitude and behavior.

Based on the research, it is found that the family counseling is a good alternative method for the family who have children with autism. The inclusive school can implement this method for caring an effective counseling to the parents with autistic children.

\section{REFERENCE}

Budiman, M. (2011). Penanganan Dini bagi Anak Autis. Jakarta: Intisari.

Cevilla, C. G. (2014). Pengantar Metode Penelitian. Jakarta: Universitas Indonesia.

Danuatmaja, B. (2008). Terapi Anak Autis Di Rumah. Jakarta: Puspa Swara.

Delhpie, B. (2009). Psikologi Perkembangan (Anak Berkebutuhan Khusus). Sleman: Intan Sejati Klaten.

Howard, A. L. (2012). Family Psychology. Sciencebased Intervention. Woshington DC: APA.

Huzaemah. (2010). Kenali Autisme Sejak Dini. Jakarta: Pustaka Populer Obor.
Latipun. (2008). Psikologi Konseling. Malang: UMM Press.

Mulana, M. (2013). Anak Autis: Mendidik Anak Autis dan Gangguan Mental Lain. Jogjakarta: Ar-Ruzz Media Group.

Nainggolan, J. A. (2016) Penyesuaian Diri Orangtua Dan Keberfungsian Keluarga Yang Memiliki Anak Penyandang Autisme Di Samarinda. Journal Psikologi, 4(2).

Pratiwi, R. P. (2013). Kiat Sukses Mengasuh Anak Berkebutuhan Khusus. Yogyakarta: ArRuzz Media.

Pujosuwarno, S. (2007). Bimbingan dan Konseling Keluarga. Yogyakarta: Menara Mas Offset.

Safaria, T. (2010). Autisme. Yogyakarta: Graha Ilmu.

Suryana, A. (2004). Terapi Autisme, Anak Berbakat dan Hiperaktif. Jakarta: Progress.

Susanto, S. E. (2014). Penerimaan Orang tua terhadap Kondisi Anaknya yang Menyandang Autisme di Rumah Terapis Little Star. PSIKOSAINS (Jurnal Penelitian dan Pemikiran Psikologi), 9(2), 140152.

Suteja, J. (2014). Bentuk dan metode terapi terhadap anak autisme akibat bentukan perilaku sosial. Edueksos: Jurnal Pendidikan Sosial \& Ekonomi, $3(1)$.

Wijayakusuma, H. (2011). Psikoterapi Anak Autisme. Jakarta: Pustaka Populer.

Williams, C., \& Wright, B. (2007). How to Live with Autism and Asperger Syndrome, Strategi Praktis Bagi Orangtua dan Guru Anak Autis. Cetakan Pertama. Jakarta: Dian Rakyat.

Yuwono, D. (2010). Pengembangan Model Program Bimbingan dan Konseling Berbasis Karakter di Sekolah Dasar. Jurnal Bimbingan Konseling, 3(1). 73-75. 